Prof. Chrystal's condensation hygrometer, though its temperature was lowered to $9^{\circ} \mathrm{o}$. These quite exceptional arid states of the air on Ben Nevis during the past summer are of the greatest interest, especially in their relations to the unprecedentedly severe early frosts which were so destructive to the potato and cereal crops over extensive breadths of the country during September. It was reported that since the middle of August subscriptions to the amount of about $300 \mathrm{l}$. had been already received from the original subscribers, and it was resolved to make the claims of the Observatory more widely known. At the same meeting the Council resolved that the discussion of the ob ervations of the temperature of the sea round Scotland be undertaken by the Scottish Marine Station at Granton chiefly with the view of constructing isothermal maps of the sea for each month round the Scottish coasts. The Secretary reported that he had during the summer inspected twenty-six of the Society's stations. The Duke of Buccleuch, and Messrs. Donald Beith, W.S.; Robert Irvine of Royston; B. N. Peach, Geological Survey ; and John Horn, also of the Geological Survey, were elected members of the Society.

\section{ON THE INTELLIGENCE OF THE DOG}

THE man and the dug have lived together in more or less intimate association for many thousands of years, and yet it must be confessed that they know comparatively little of one another. That the dog is a loyal, true, and affectionate friend must be gratefully admitted, but when we come to consider the psychical nature of the animal, the limits of our knowledge are almost immediately reached. I have elsewhere suggested that this arises very much from the fact that hitherto we have tried to teach animals, rather than to learn from them-to convey our ideas to them, rather than to devise any language or code of signals by means of which they might communicate theirs to us. The former may be more important from a utilitarian point of view, though even this is questionable, but psychologically it is far less interesting. Under these circumstances it occurred to me whether some such system as that followed with deaf mutes, and especially by Dr. Howe with Laura Bridgman, might not prove very instructive if adapted to the case of dogs. I have tried this in a small way with a black poodle named "Van." I took two pieces of cardboard about ro inches by 3 , and on one of them printed in large letters the word "food," leaving the other blank. I then placed two cards over two saucers, and in the one under the "food" card put a little bread and milk, which "Van," after having his attention called to the card, was allowed to eat. This was repeated over and over again till he had had enough. In about ten days he began to distinguish between the two cards. I then put them on the floor and made him bring them to me, which he did readily enough. When he brought the plain card I simply threw it back, while, when he brought the food card, I gave him a piece of bread, and in about a month he had pretty well learned to realise the difference. I then had some other cards printed with the words " out," "tea," "bone," "water," spelt phonetically, so as not to trouble him by our intricate spelling, and a certain number also with words to which I did not intend him to attach any significance, such as " nought," "plain," "ball," \&c. "Van" soon learned that bringing a card was a request, and soon learned to distinguish between the plain and printed cards; it took him longer to realise the difference between words, but he gradually got to recognise several, such as "food," "out," "bone," "tea," \&c. If he was asked whether he would like to go out for a walk, he would joyfully pick up the "out" card, choosing it from several others, and bring it to me, or run with it in evident triumph to the door. I need hardly say that the cards were not always put in the same places. They were varied quite indiscriminately and in a great variety of positions. Nor could the dog recognise them by scent. They were all alike, and all continually handled by us. Still I did not trust to that alone, but had a number printed for each word. When, for instance, he brought a card with "food" on it, we did not put down the same identical card, but another bearing the same word, when he had brought that a third, then a fourth, and so on. For a single meal, therefore, eighteen or twenty cards would be used, so that he evidently is not guided by scent. No one who has seen him look down a row of cards and pick up the one he wanted could, I think, doubt that in bringing a card he feels he is making a request, I Abstract of paper by Sir John Lubbock, Bart., M.P., F.R.S., read at
the Aberdeen meeting of the British Assjciation. and that he can not only distinguish one card from another, but also associate the word and the object. This is, of course, only a beginning, but it is, I venture to think, suggestive, and might be carried further, though the limited wants and aspirations of the animal constitute a great difficulty. My wife has a very beautiful and charming collie, "Patience," to which we are much attached. This dog was often in the room when "Van" brought the food card, and was rewarded with a piece of bread. She must have seen this thousands of times, and she begged in the usual manner, but never once did it occur to her to bring a card. She did not touch or indeed even take the slightest notice of them. I then tried the following experiment:-I prepared six cards about ro inches by three, and coloured in pairs-two yellow, two blue, and two orange. I put three of them on the floor, and then holding up one of the others, endeavoured to teach "Van" to bring me the duplicate. That is to say, that if the blue was held up, he should fetch the corresponding colour from the floor; if yellow, he should fetch the yellow, and so on. When he brought the wrong card he was made to drop it, and return for another till he brought the right one, when he was rewarded with a little food. The lessons were generally given by my assistant, Miss Wendland, and lasted half an hour, during which time he brought the right card on an average about twenty-five times. I certainly thought that he would soon have grasped what was expected of him. But no. We continued the lessons for nearly three months, but as a few days were missed, we may say for ten weeks, and yet at the end of the time I cannot say that "Van" appeared to have the least idea of what was expected of him. It seemed a matter of pure accident which card he brought. There is, I believe, no reason to doubt that dogs can distinguish colours; but as it was jus possible that "Van" might be colour blind, we then repeated the same experiment, only substituting for the coloured cards others marked respectively I., II., and III. This we continued for another three months, or, say, allowing for intermissions, ten weeks, but to my surprise entirely without success. I was rather disappointed at this, as, if it had succeeded, the plan would have opened out many interesting lines of inquiry. Still in such a case one ought not to wish for one result more than another, as of course the object of all such experiments is merely to elicit the truth, and our result in the present case, though negative, is very interesting. I do not, however, regard it as by any means conclusive, and should be glad to see it repeated. If the result proved to be the same, it would certainly imply very little power of combining even extremely simple ideas. I then endeavoured to get some insight into the arithmetical condition of the dog's mind. On this subject I have been able to find but little in any of the standard works on the intelligence of animals. Considering, however, the very limited powers of savage men in this respect-that no Australian language, for instance, contains numerals even up to four, no Australian being able to count his own fingers even on one hand-we cannot be surprised if other animals have made but little progress. Still, it is surprising that so little attention should have been directed to this subject. Leroy, who, though he expresses the opinion that "the nature of the soul of animals is unimportant," was an excellent observer, mentions a case in which a man was anxious to shoot a crow. "To deceive this suspicious bird, the plan was hit upon of sending two men to the watch-house, one of whom passed on, while the other remained; but the crow counted and kept her distance. The next day three went, and again she perceived that only two retired. In fine, it was found necessary to send five or six men to the watch-house to put her out in her calculation. The crow, thinking that this number of men had passed by, lost no time in returning." From this he inferred that crows could count up to four. Lichtenberg mentions a nightingale which was said to count up to three. Every day he gave it three mealworms, one at a time; when it had finished one it returned for another, but after the third it $\mathrm{kn}: \mathrm{w}$ that the feast was over. I do not find that any of the recent writers on the intelligence of animals, either Buchner, or Peitz, or Romanes, in either of his books, give any additional evidence on this part of the subject. There are, however, various scattered notices For instance, there is an amusing and suggestive remark in Mr. Galton's interesting " Narrative of an Explorer in Tropical South Africa." After describing the Damara's weakness in calculations, he says :-- "Once while I watched a Damara floundering hopelessly in a calculation on one side of me, I observed 'Dinah,' my spaniel, equally embarrassed on the other; she was overlooking half a dozen of her new-born puppies, 
which had bcen removed two or three times from her, and her anxiety was excessive, as she tried to find out if they were all present, or if any were still missing. She kept puzzling and running her eyes over them backwards and forwards, but could not satisfy herself. She evidently had a vague notion of counting, but the figure was too large for her brain. Taking the two as they stood, dog and Damara, the comparison reflected no great honour on the man." But even if "Dinah" had been clear on this subject, it might be said that she knew each puppy personally, as collies are said to know sheep. The same remark applies generally to animals and their young. Swans, for instance, are said to know directly if one of their cygnets is missing, but it is probable that they know each young bird individually. This explanation applies with less force to the case of eggs. According to my bird-nesting recollections, which I have refreshed by more recent experience, if a nest contains four eggs, o:le may safely be taken; but if two are removed, the bird generally deserts. Here, then, it would seem as if we had some reason for supposing that there is sufficient intelligence to distinguish three from four. An interesting consideration arises with reference to the number of the victims allotted to each cell by the solitary wasps. One species of Ammophila considers one large caterpillar of Notua segetum enough; one species of Eumenes supplies its young with 5 victims; another 10,15 , and even up to 24 . The number appears to be constant in each species. How does the insect know when her task is fulfilled ? Not by the cell being filled, for if : ome be removed she does not replace them. When she has brought her complement she considers her task accomplished, whether the victims are still there or not. How, then, does she know when she has made up the number 24? Perhaps it will be said that each species feels some mysterious and innate tendency to provide a certain number of victims. This would, under no circumstances, be any explanation; but it is not in accordance with the facts. In the genus Eumenes the males are much smaller than the females. Now, in the hive-bees, humble-bees, wasps, and other insects, where such a difference occurs, but where the young are directly fed, it is of course obvious that the quantity can be proportioned to the appetite of the grub. But in insects with the habits of Eumenes and Ammophila the case is different, because the food is stored up once for all. Now, it is evident that if a female grub was supplied with only food enough for a male she would starve to death; while if a male grub were given enough for a female it would have too much. No such waste, however, occurs. In some mysterious manner the mother knows whether the egg will produce a male or female grub, and apportions the quantity of food accordingly. She does not change the species or size of her prey; but if the egg is male she supplies 5 ; if female, 10 victims. Does she count? Certainly this seems very like a commencement of arithmetic. At the same time it would be very desirable to have additional evidence how far the number is really constant. Considering how much has been written on instinct, it seems surprising that so little attention has been directed to this part of the subject. One would fancy that there ought to be no great difficulty in determining how far an animal could count; and, whether, for instance, it conld realise some very simple sum, such as that two and two make four. But when we come to consider how this is to be done the problem ceases to appear so simple. We tried our dogs by putting a a piece of bread before them and preventing them from touching it until we had counted seven. To prevent ourselves from unintentionally giving any indication we used a metronome (the instrument used for giving time when practising the pianoforte), and to make the beats more evident we attached a slender rod to the pendulum. It certainly seemed as if our dogs knew when the moment of permission had arrived ; but their movement of taking the bread was scarcely so definite as to place the matter beyond a doubt. Moreover, dogs are so very quick in seizing any indication given them, even unintentionally, that, on the whole, the attempt was not satisfactory to my mind. I was the more discouraged from continuing the experiment in this manner by an account Mr. Huggins gave me of a very intelligent dog belonging to him. A number of cards were placed on the ground, numbered respectively $1,2,3$, and so on up to Io. A question is then asked : the square root of 9 or 16 , or such a sum as $6 \times 52-3$. Mr. Huggins pointed consecutively to the cards, and the dor barked when he came to the right one. Now Mir. Huggins dill not consciously give the dog any sign, yet so quick was the dog in scizing the slightest indication, that he was able to give the correct answer. This observation seems to me of great interest in connection with the so-called "thought-reading." No one, I suppose, will imagine that there was in this case any "thought-reading" in the sense in which this word is used by Mr. Bishop and others. Evidently "Kepler" seized upon the slight indications unintentionally given by $\mathrm{Mr}$. Huggins. The observation, however, shows the great difficulty of the subject. I have ventured to bring this question before the Section partly because I shall be so much obliged if any lady or gentleman present will favour me with any suggestions; and partly in hope of inducing others with more leisure and opportunity to carry on similar observations, which I cannot but think must lead to interesting results.

Dr. Flower remarked that the crowded state of the room was sufficient evidence of the interest taken in whatever of the numerous subjects Sir John Lubbock cared to enlighten them upon. Sir John Lubbock was unable to make his dog count seven, but a dog at a place where he (Dr. Flower) was living recently certainly knew when the seventh day of the week came. The dog, most cager on every other day of the week to go for a walk, betrayed no desire to go on Sunday when his master took up hi hat and stick to go to church. It struck him that the methor which Sir John had adopted was the only one by which the could put themselves in reiation to the minds of these animalsnamely, the method of kindness and encouragement. Too many had tried to do these things by a system of intimidation and cruelty, but he did not think they could really know what dogs could do, and bring out their faculties, without patience and perseverance, encouragement, and uniform kindness.

Miss Catherine Rae explained the way in which she got a dog, within three weeks, to ring a bell. She began by letting "Tiny" smell the bone of a mutton chop, and then tied the bone to the string of the bell. At first "Tiny" was in a great tremor, but, by taking her very kindly and stroking her, she found that she could induce her to pull at the bone and so to ring the bell. After that she tied a small piece of wood to the string, but the dog would not pull it. At last she pulled her gently back till the bell rang, and in this way, in the short course of three weeks, with not more than one or two lessons a day, the dog would go and ring the bell by being told-"' 'Tiny,' go and ring the bell." At the end of three weeks she gave an evening party, and during the evening they were all electrified by the sudden and violent ringing of the bell. "Tiny" had been neglected to be indulged with any tit-bit, and had taken this means of receiving attention.

Miss Becker said, with regard to the experiments with the crow mentioned by Sir John, to show that it could not count beyond three, that something of the same kind might happen with a person. Place three eggs upon the table, and any one could say there were three; but if there were twelve he would require to count them to be sure of the number.

Mr. C. C. Walker gave an instance of a dog being taught politics. He belonged to a family where Liberal politics prevailed, and the dog showed his sympathy by growling fearfully when the name of "Dizzy" was mentioned, and at the name of his master giving expression to unbounded delight. Similar demonstrations at public meetings, he acdded, were often made with as little intelligence as those of the $\mathrm{dog}$.

Some other remarks were made, one gentleman suggesting that as long as the dog was ignorant of the words " one," "two," "three," "four," he would not be able to count or get beyond the mere perception of magnitude.

Sir John Lubbock thought with reference to the question of Sunday that there were so many slight indications in the household generally to distinguish the day that he had never been able to regard that as proof of a dog counting, although it was a very interesting fact in itself. As regards several of the other cases they were clever tricks, but his suggestion was to operate in exactly the opposite direction; not to teach the dog, but to enable the dog to communicate with us.

\section{NITROGEN IN THE SOIL}

$\mathrm{FACH}$ of the elements required for building up the frame of animals and plants is of equal importance from a scientific standpoint, but in agriculture the various salts and substances which yield food for crops or for cattle must necessarily be valued according to their cost. There are exceptions to this rule, no doubt. Gypsum is a cheap manure, but it has sometimes doubled the clover crop, and kainit salts are comparatively cheap. Yet 